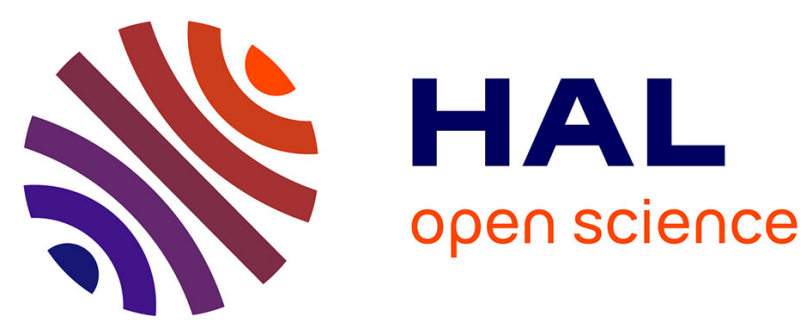

\title{
Anode supported single chamber solid oxide fuel cells operating in exhaust gases of thermal engine
}

\author{
Pauline Briault, Mathilde Rieu, Richard Laucournet, Bertrand Morel, \\ Jean-Paul Viricelle
}

\section{- To cite this version:}

Pauline Briault, Mathilde Rieu, Richard Laucournet, Bertrand Morel, Jean-Paul Viricelle. Anode supported single chamber solid oxide fuel cells operating in exhaust gases of thermal engine. Journal of Power Sources, 2014, 268, pp.356-364. 10.1016/j.jpowsour.2014.06.061 . hal-01056363

\section{HAL Id: hal-01056363 https://hal.science/hal-01056363}

Submitted on 21 Aug 2014

HAL is a multi-disciplinary open access archive for the deposit and dissemination of scientific research documents, whether they are published or not. The documents may come from teaching and research institutions in France or abroad, or from public or private research centers.
L'archive ouverte pluridisciplinaire HAL, est destinée au dépôt et à la diffusion de documents scientifiques de niveau recherche, publiés ou non, émanant des établissements d'enseignement et de recherche français ou étrangers, des laboratoires publics ou privés. 
Anode supported single chamber solid oxide fuel cells operating in exhaust gases of thermal engine

Pauline BRIAULT ${ }^{\text {a }}$, Mathilde RIEU ${ }^{\mathrm{a},{ }^{*}}$, Richard LAUCOURNET ${ }^{\mathrm{b}}$, Bertrand MOREL ${ }^{\mathrm{b}}$, JeanPaul VIRICELLE ${ }^{\mathrm{a}}$

${ }^{a}$ Ecole Nationale Supérieure des Mines, SPIN-EMSE, PRESSIC Department, CNRS:UMR5307, LGF, F-42023 Saint-Etienne

${ }^{\mathrm{b}}$ French Atomic Energy and Alternative Energies Commission CEA-LITEN, 17, rue des martyrs 38054 Grenoble Cedex 9

* Corresponding author: M. Rieu, E-mail address: rieu @emse.fr; Tel.:+33 4774202 82; Fax:+33 477499694 


\begin{abstract}
$\underline{\text { Abstract }}$
This project deals with the development and the electrochemical characterization of anode supported single chamber SOFC in a simulated environment of thermal engine exhaust gas. In the present work, a gas mixture representative of exhaust conditions is selected. It is composed of hydrocarbons (HC: propane and propene), oxygen, carbon monoxide, carbon dioxide, hydrogen and water. Only oxygen content is varied leading to different gas mixtures characterized by three ratios $\mathrm{R}=\mathrm{HC} / \mathrm{O}_{2}$. Concerning the cell components, a cermet made of nickel and an electrolyte material, $\mathrm{Ce}_{0.9} \mathrm{Gd}_{0.1} \mathrm{O}_{1.95}(\mathrm{CGO})$ is used as anode and two cathode materials, $\mathrm{La}_{0.6} \mathrm{Sr}_{0.4} \mathrm{Co}_{0.2} \mathrm{Fe}_{0.8} \mathrm{O}_{3-\delta}(\mathrm{LSCF})$ and $\mathrm{Pr}_{2} \mathrm{NiO}_{4+\delta}(\mathrm{PNO})$, are evaluated. The prepared cells are investigated in the various gas mixtures for temperatures ranging from $450^{\circ} \mathrm{C}$ to $600^{\circ} \mathrm{C}$. Ni$\mathrm{CGO} / \mathrm{CGO} / \mathrm{LSCF}-\mathrm{CGO}$ cell has delivered a maximum power density of $15 \mathrm{~mW} \mathrm{~cm}{ }^{-2}$ at $500^{\circ} \mathrm{C}$ with $\mathrm{R}=\mathrm{HC} / \mathrm{O}_{2}=0.21$, while lower power densities are obtained for the other ratios, $\mathrm{R}=0.44$ and $\mathrm{R}=0.67$. Afterwards, LSCF and PNO cathode materials are compared and LSCF is found to deliver the highest power densities. Finally, by improving the electrolyte microstructure, some cells presenting a maximum power density of $25 \mathrm{~mW} \mathrm{~cm}^{-2}$ at $550^{\circ} \mathrm{C}$ are produced. Moreover, up to $17 \%$ of initial $\mathrm{HC}$ are eliminated in the gas mixture.
\end{abstract}

Keywords: Single chamber SOFC, energy recovery, unburned hydrocarbons, pollutant emissions reduction 


\section{$\underline{\text { 1. Introduction }}$}

Solid oxide fuel cells are usually described as devices able to convert chemical energy into electrical energy. Conventional solid oxide fuel cells are separated into two compartments containing each electrode split by a gastight electrolyte. Fuel (hydrogen, in most cases) and oxidant (oxygen or air) feed directly each chamber and a special attention is paid to separate carefully the two gases. At the cathode side, oxygen is reduced into oxygen ions (reaction 1) which travel through the electrolyte to the anode side, where they oxidize hydrogen into water (reaction 2). Electrons produced by hydrogen oxidation are then drawn to the cathode through an external circuit. The overall reaction is the chemical oxidation of hydrogen to water (reaction 3 ).

$$
\begin{array}{ll}
\mathrm{O}_{2}+4 \mathrm{e}^{-} \rightarrow 2 \mathrm{O}^{2-} & \text { (reaction } 1) \\
\mathrm{H}_{2}+\mathrm{O}^{2-} \rightarrow \mathrm{H}_{2} \mathrm{O}+2 \mathrm{e}- & \text { (reaction 2) } \\
\mathrm{H}_{2}+1 / 2 \mathrm{O}_{2} \rightarrow \mathrm{H}_{2} \mathrm{O} & \text { (reaction 3) }
\end{array}
$$

Since the early nineties [1-2], SOFC have been studied in a new configuration where anode and cathode are exposed to the same gas mixture in a single chamber. The Single Chamber SOFCs (SC-SOFCs) are particularly interesting [3-4] due to the absence of sealing between the two usual compartments, removing one of main challenges of conventional SOFCs. However, in SC-SOFC configuration, hydrogen cannot be used as a fuel since hydrogen-air mixtures are highly reactive, thus hydrocarbons, able to form hydrogen through partial oxidation (reaction 4), are most commonly used in the gas mixture.

$\mathrm{C}_{\mathrm{n}} \mathrm{H}_{\mathrm{m}}+\mathrm{n} / 2 \mathrm{O}_{2} \rightarrow \mathrm{n} \mathrm{CO}+\mathrm{m} / 2 \mathrm{H}_{2} \quad$ (reaction 4) 
As there is no difference in the gas composition at each side of the cell, single chamber operation principle is based on the difference of electrodes catalytic activity towards hydrocarbon oxidation. When no current is drawn, the depletion of oxygen at the anode and the maximum concentration of oxygen at the cathode lead to an oxygen partial pressure gradient between both sides of the cell involving an open circuit voltage (OCV) creation.

The single chamber configuration has several advantages in comparison with conventional SOFCs: new cell geometries, stack assembly and cells miniaturization are more easily conceivable. These advantages open the way to new applications such as energy recovery and pollutant emission reduction. In such applications, cells might be embedded at the outlet of engine and could turn unburned hydrocarbons present in the exhaust gas into electricity allowing for instance the energy supplying of electronic devices in vehicles. More largely, such energy conversion device can address all applications where hydrocarbons are burnt such as stationary power plants where environmental and efficiency issues are identified.

To date, only a few authors have investigated such a system. Herman et al. [5] and Uchiyama [6] described equivalent devices in patents. Particularly, N. Uchiyama collaborated on testing such a system in real conditions with T. Hibino's group; two articles dealing with the results were published in 2008 [7-8]. Concerning the gas mixture used for tests, patents and articles expose only evasive or simplified compositions. Herman's patent [5] describes a mixture composed of hydrocarbons (e.g. methane, ethane...), hydrogen and oxygen without any accurate composition. In Uchiyama's work [6], the studied atmosphere is composed of hydrocarbons, carbon oxides and air without any further details. The only work reporting the concentration of studied stream for 
single cell test was published by Hibino's group [7-8]. A mixture of four hydrocarbons (methane, ethane, propane and butane) with $1000 \mathrm{ppm}$ of each hydrocarbon specie and with oxygen ranging from 1250 to 15000 ppm is reported. For an electrolyte supported $\mathrm{Ni}-\mathrm{Ce}_{0.8} \mathrm{Sm}_{0.2} \mathrm{O}_{1.9}$ (SDC)/ $8 \% \mathrm{Y}_{2} \mathrm{O}_{3}-\mathrm{ZrO}_{2}(\mathrm{YSZ}) / \mathrm{La}_{0.8} \mathrm{Sr}_{0.2} \mathrm{MnO}_{3}$ (LSM) single cell, an open circuit voltage and a maximum power density respectively $1100 \mathrm{mV}$ and $20 \mathrm{~mW} \mathrm{~cm}^{-2}$ were measured at $800^{\circ} \mathrm{C}$, a temperature not really considered as realistic for the aimed application. Then, an output power of $1.2 \mathrm{~W}$ was delivered by a twelve-cells stack embedded at the exit of a scooter engine, which is still not high enough to provide energy to electronic devices included in a vehicle but proves the feasibility of such energy recovery system. Nevertheless, no exact composition of exhaust gas is given for the stack test at the exit of the scooter.

In the present work, further improvements including gas mixture composition, architecture of the cell and materials are initiated. Indeed, the selected gas mixture is based on a more realistic composition of exhaust gas flowing inside the catalytic converter of a thermal engine. The influence of oxygen content is investigated on the performances of cells. Anode supported architecture is selected instead of the usual electrolyte supported since it has proven an ability to deliver higher power densities by a lower resistance of thinner electrolyte [9]. For the cell components, most performing materials are selected. $\mathrm{Ce}_{0.9} \mathrm{Gd}_{0.1} \mathrm{O}_{1.95}(\mathrm{CGO})$ is used as the electrolyte material due to a high ionic conductivity at intermediate temperature range: $0.025 \mathrm{~S}$ $\mathrm{cm}^{-1}$ at $600^{\circ} \mathrm{C}[10]$. The anode is a typical cermet composed of nickel and electrolyte material. Two cathode materials are compared regarding the application, $\mathrm{La}_{0.6} \mathrm{Sr}_{0.4} \mathrm{Co}_{0.2} \mathrm{Fe}_{0.8} \mathrm{O}_{3-\delta}(\mathrm{LSCF})$, a well-known cathode material [11-12] and $\mathrm{Pr}_{2} \mathrm{NiO}_{4+\delta}$ (PNO) only used up to now for conventional SOFCs [13]. Finally, electrolyte microstructure is improved in order to enhance performances. 


\section{Experimental}

\subsection{Exhaust stream composition}

The gas mixture used in this project is based on data provided by an engine manufacturer corresponding to the gas composition after the catalytic converter. However, it has been slightly modified to fit to laboratory conditions. The gas stream is hence composed of hydrocarbons (HC): 1/3 propane and 2/3 propene, and oxygen but hydrocarbons oxidation products are added: hydrogen, carbon monoxide, water and carbon dioxide; and finally nitrogen is used as balance gas. Three compositions are employed presenting different ratios $\mathrm{R}\left(\mathrm{HC} \mathrm{O}_{2}\right): \mathrm{R}=0.21$ corresponding to oxygen content required for total oxidation, $\mathrm{R}=0.67$ corresponding to partial oxidation and $\mathrm{R}=0.44$, an intermediate value. The compositions are reported in table 1 . The experiments were done at atmospheric pressure, so the oxygen partial pressure is ranging from 1.3 mbar (corresponding to $\mathrm{R}=0.67$ ) to $4.7 \mathrm{mbar}$ (corresponding to $\mathrm{R}=0.21$ ). It is also noteworthy that there is more than $90 \%$ of nitrogen in the composition meaning that the mixture contains very low levels of reactive species.

\subsection{Materials and cells preparation}

All raw materials used for electrochemical tests and cells manufacturing are commercial powders. Suppliers and powder specifications are given in table 2.

Anode supported cells are prepared by screen printing the electrolyte on the green anode made by tape casting. The slurry for tape casting is prepared according to the formulation previously 
described in the literature [14]. The powders mixture used in this paper is composed of $60 \mathrm{wt} \%$ of $\mathrm{NiO}$ from Novamet and $40 \mathrm{wt} \%$ of CGO from Rhodia. Electrolyte ink is composed of $70 \mathrm{wt} \%$ of CGO from Fuel Cell Materials and $30 \mathrm{wt} \%$ of a solvent-binder mixture (terpineol mixed with 5 wt $\%$ of ethyl cellulose). Various thicknesses of electrolyte are prepared by screen printing with respectively 3, 5 or 7 layers. The half cells are then co-sintered in two main steps. At first, a slow heating rate $\left(60^{\circ} \mathrm{C} \mathrm{h}^{-1}\right)$ is performed up to $600^{\circ} \mathrm{C}$ with a $1 \mathrm{~h}$-dwell time to remove the binders contained in the anode tape. Then, a faster heating rate towards $1400^{\circ} \mathrm{C}$ and a $6 \mathrm{~h}-\mathrm{dwell}$ time are respected to sinter the half cells. The reduction of the anode is carried out at $650^{\circ} \mathrm{C}$ for 4 hours in a $6 \% \mathrm{H}_{2}$ atmosphere. Two cathode layers are then screen-printed on the reduced half-cell using an ink composed of $70 \mathrm{wt} \%$ cathode material and $30 \mathrm{wt} \%$ CGO (Fuel Cell Materials) as solid content. A first heating at $300^{\circ} \mathrm{C}$ for $30 \mathrm{~min}$ in air is done to remove cathode ink binder and then cathode are annealed at $1100^{\circ} \mathrm{C}$ in argon to avoid any anode reoxidation. A gold mesh is screen printed on top of the cathode to collect correctly the current during the experiment. Same heating treatment in air $\left(300^{\circ} \mathrm{C}, 30 \mathrm{~min}\right)$ as for the cathode is carried out and the gold mesh is finally annealed at $900^{\circ} \mathrm{C}$ for $2 \mathrm{~h}$ under argon.

\subsection{Fuel cells characterization}

In SC-SOFC system, the geometry of the cell but also of the whole test chamber have a great influence on performances. That's why a schema of the experimental test bench and photographs of the sample holder are reported in Figure 1. Experiments are performed in a horizontal tubular furnace. The investigated cell is placed in an alumina sample holder between two gold meshes. The alumina sample holder is composed of two symmetrical parts to maintain the cell parallel to the flow of gas inlet. The cell is just put between the gold meshes and there is no load applied to 
press the contact except the weight of the alumina top (i.e. 40 grams). Furthermore, the position of the cell into the sample holder also allows to divide the flow by half between anode and cathode sides.

The incoming gas mixture feeding the reactor is monitored by mass flow meters. Water is generated by nitrogen bubbling at controlled temperature. At the beginning of each test, temperature is increased to $600^{\circ} \mathrm{C}$ under nitrogen at $10 \mathrm{~L} \mathrm{~h}^{-1}$. Then, gas mixture is supplied to the cell during the isothermal stage at $60 \mathrm{~L} \mathrm{~h}^{-1}$. This flow rate was fixed to avoid homogeneous catalysis in the gas phase itself. Indeed, at high temperature and at lower flow rate, the gas compositions studied were not stable and gas decomposition occurred without any cell. Various temperature dwells are done every $50^{\circ} \mathrm{C}$ between $600^{\circ} \mathrm{C}$ and $450^{\circ} \mathrm{C}$ to perform characterizations. Then the cooling is done under nitrogen to avoid other reaction. Four wires electrical measurements are performed at each temperature dwell. Gold meshes on each side of the cell are used to collect current and two gold wires are stuck on each gold mesh. Electrical and electrochemical measurements are performed by a VersaSTAT3 from Princeton Applied Research. Impedance spectroscopy measurements were done at open circuit voltage with frequency ranging from $100 \mathrm{kHz}$ to $0.1 \mathrm{~Hz}$ using an electrical perturbation of $20 \mathrm{mV}$. In parallel, the gas composition is monitored at the outlet of the set-up by an in line micro gas chromatograph (SRA Instruments microGC3000). The water content is measured thanks to a humidity sensor and condensed before the gas flows to the micro-chromatograph. After tests, cells microstructures are characterized by a scanning electron microscope (SEM) Jeol JSM 6500. ImageJ software is used to evaluate the porosity of electrolyte. Micrographs obtained by SEM (about 10 micrographs) are analyzed with this image processing program to get a porosity average. 
$\mathrm{X}$-ray diffraction (XRD) analyses are carried out on a Siemens D5000 using $\mathrm{Cu} \mathrm{K} \alpha$ radiation at $40 \mathrm{kV}$ and $40 \mathrm{~mA}$. After all performed experiments, no nickel oxidation is evidenced in the studied conditions.

\subsection{Specific data calculation}

Fuel utilization is calculated from electrical measurements, by assuming it is defined as the faradaic efficiency: $\varepsilon_{\mathrm{f}}$ (Equation 1).

Equation 1: $\quad \varepsilon_{f}=\frac{I}{I_{t h}}$

with I: current delivered by the cell and $\mathrm{I}_{\mathrm{th}}$ : theoretical current obtained if the fuels are completely consumed.

In order to calculate this efficiency, the four fuels present in the gas mixture have to be taken into account: $\mathrm{H}_{2}, \mathrm{CO}, \mathrm{C}_{3} \mathrm{H}_{8}$ and $\mathrm{C}_{3} \mathrm{H}_{6}$. Their direct electrochemical oxidation reactions are considered for the calculation of $\mathrm{I}_{\text {th }}$ (reactions 2, 5, 6 and 7).

$\mathrm{CO}+\mathrm{O}^{2-} \rightarrow \mathrm{CO}_{2}+2 \mathrm{e}-\quad$ (reaction 5$)$

$\mathrm{C}_{3} \mathrm{H}_{8}+10 \mathrm{O}^{2-} \rightarrow 4 \mathrm{H}_{2} \mathrm{O}+3 \mathrm{CO}_{2}+20 \mathrm{e}-\quad$ (reaction 6)

$\mathrm{C}_{3} \mathrm{H}_{6}+9 \mathrm{O}^{2-} \rightarrow 3 \mathrm{H}_{2} \mathrm{O}+3 \mathrm{CO}_{2}+18 \mathrm{e}-\quad$ (reaction 7)

The content of each fuel species, defined in table 1, is also used to calculate the theoretical current density $\mathrm{I}_{\mathrm{th}}$ according to equation 2 .

Equation 2: $\quad I_{t h}=\sum z F \frac{d n(f u e l)}{d t}$

with z: number of electrons involved into the considered reaction $(2,5,6$ or 7$)$, F: Faraday constant and dn(fuel)/dt: molar flow of the aimed compound. 
From gas analysis, hydrocarbons conversion rate, $\chi$, is calculated according to equation 3 . This parameter allows to evaluate hydrocarbons emission reduction at open circuit voltage.

Equation 3: $\quad \chi=\frac{\left(H C_{\text {in }}-H C_{\text {out }}\right)}{H C_{\text {in }}} .100$

with $\mathrm{HC}_{\text {in }}$ and $\mathrm{HC}_{\text {out }}$ : hydrocarbons volume content at the inlet and the outlet, respectively.

\section{Results and discussion}

\subsection{Influence of ratio $\mathrm{R}=\mathrm{HC} / \mathrm{O}_{2}$ on $\mathrm{Ni}-\mathrm{CGO} / \mathrm{CGO} / \mathrm{LSCF}-\mathrm{CGO}$ cell performances}

LSCF is employed for these tests due to a more suitable electrochemical behavior as cathode material [11-12] and a better chemical stability under the gas mixture [15].

As illustrated in Figure 2, a typical cell used for experiment is composed of a $15 \mu \mathrm{m}$ cathode (corresponding to 2 screen printed layers) and a $20 \mu \mathrm{m}$ ( 3 screen printed layers) electrolyte on top of a $400 \mu \mathrm{m}$ thick anode.

Polarization curves are measured at different temperatures ranging from $600^{\circ} \mathrm{C}$ to $450^{\circ} \mathrm{C}$, each $50^{\circ} \mathrm{C}$, for each ratio $\mathrm{R}=\mathrm{HC} / \mathrm{O}_{2}$ defined in table 1 .

3.1.1. $R=0.67$ 
For the gas mixture with the lower oxygen content, i.e. $\mathrm{R}=0.67$, electrical measurements show low performances reaching only $2.5 \mathrm{~mW} \mathrm{~cm}^{-2}$ at $450^{\circ} \mathrm{C}$ as a maximum power density. SEM analysis after test, reported in Figure 3, revealed carbon whiskers and nodules in the anode layer. Furthermore, carbon deposit is also visible after the cell test, with black particles detached from the anode. These carbon particles may be a product due to carbon cracking (reaction 8) and Boudouard equilibrium (reaction 9).

$\mathrm{C}_{\mathrm{n}} \mathrm{H}_{\mathrm{m}} \rightarrow \mathrm{x} \mathrm{C}+\mathrm{C}_{\mathrm{n}-\mathrm{x}} \mathrm{H}_{\mathrm{m}-\mathrm{y}}+\mathrm{y} / 2 \mathrm{H}_{2} \quad$ (reaction 8)

$2 \mathrm{CO} \Leftrightarrow \mathrm{C}+\mathrm{CO}_{2} \quad$ (reaction 9)

The carbon particles formation explain the poor performances obtained during cell operation for the $\mathrm{R}=0.67$ ratio. Indeed, carbon particles may reduce the efficiency of nickel catalytic sites [16].

\subsubsection{Comparison of $R=0.21$ and $R=0.44$}

Electrical performances of Ni-CGO/CGO/LSCF-CGO cells operated under $\mathrm{R}=0.21$ and $\mathrm{R}=0.44$ are reported in Figure 4. For easier comparison, OCV and maximum power densities are determined from the polarization curves and their evolutions are reported in Figure 5 as a function of the temperature. OCV values are relatively low, reaching $700 \mathrm{mV}$ at $450^{\circ} \mathrm{C}$. This is attributed to the porous electrolyte letting hydrogen free to go through the open porosity from anode to cathode where it consumes oxygen. Therefore, the gradient of oxygen partial pressure between electrodes decreases and the OCV as well [17-18]. Moreover, for both ratios, an evolution of OCV values is visible with the temperature. Indeed, OCV increases with the decrease of the temperature. This is in agreement with the catalytic activity of cathode towards 
hydrocarbons oxidation that decreases with the temperature decrease $[15,17]$ and so leads to a higher gradient of oxygen partial pressure between the two electrodes.

Concerning the power density, it increases with a temperature decrease. The maximum values measured are $15.2 \mathrm{~mW} \mathrm{~cm}^{-2}$ and $8.2 \mathrm{~mW} \mathrm{~cm}^{-2}$ at $500^{\circ} \mathrm{C}$ for $\mathrm{R}=0.21$ and at $450^{\circ} \mathrm{C}$ for $\mathrm{R}=0.44$, respectively. A low decrease of performances is observed for the cell tested under $\mathrm{R}=0.21$ at $450^{\circ} \mathrm{C}$.

Finally, OCV and maximum power densities are higher with the cell tested under $\mathrm{R}=0.21$. Therefore, only this ratio is kept for the following experiments.

Overall, performances obtained here are relatively low compared to the literature for single chamber SOFC operating with various hydrocarbon/air mixtures. Some hundreds of $\mathrm{mW} . \mathrm{cm}^{-2}$ are generally reached $[9,19]$. In the present study, as for Hibino's study for exhaust application (20 $\mathrm{mW} \mathrm{cm}{ }^{-2}$ at $\left.800^{\circ} \mathrm{C},[8]\right)$, the main difference is the high dilution of reactive species. Indeed, there is more than $90 \%$ of nitrogen and only about $1 \%$ of fuel.

\subsection{Influence of cathode materials under $\mathrm{R}=\mathrm{HC} / \mathrm{O}_{2}=\underline{=0.21}$}

Only tests with $\mathrm{R}=0.21$ ratio are performed with $\mathrm{PNO}$ as cathode and are exposed here in comparison with LSCF.

Polarization curves of Ni-CGO/CGO/PNO-CGO cells operated under $\mathrm{R}=0.21$ at different temperatures are shown in Figure 6. For easier comparison, evolutions of maximum power density and OCV are reported in Figure 7 for both cathodes as a function of the temperature. 
Cell with PNO cathode has shown a better OCV than the one with LSCF material for both ratios. However, no greater power density is delivered. At $600^{\circ} \mathrm{C}$, maximum power densities of both materials are equivalent. But, power densities of cells with PNO cathode decrease with temperatures decrease whereas they increase with LSCF cathode.

In literature, it is known that PNO is a non-stable structure, able to decompose in oxidizing atmospheres, into the Ruddlesden-Popper-type $\mathrm{Pr}_{4} \mathrm{Ni}_{3} \mathrm{O}_{10}$ and praseodymium oxide [20]. XRD analyses are carried out before and after cell test on this cathode and the diffractograms are reported in Figure 8. Other phases than the initial PNO are observed, mainly praseodymium oxide $\operatorname{Pr}_{6} \mathrm{O}_{11}$.

The formed phases could explain the low performances, firstly by limiting the grip of the current collector on the cathode. Indeed, it is observed that, at the end of experiments, the screen-printed gold mesh is completely delaminated from the PNO cathode. Secondly, the new phase may also reduce PNO electrochemical active phase content, thus lowering power density. Moreover, the detected parasite phases might justify the higher OCV of the Ni-CGO/CGO/PNO-CGO cell. Indeed, the catalytic activity towards $\mathrm{HC}$ oxidation of these oxides is uncertain and may be lower than the one of pure PNO, which could lead to a higher oxygen partial pressure gradient between the two electrodes and thus to higher OCV.

To conclude, PNO cathode material is considered as non-suitable for long term cell operation in the conditions investigated in the present study, and following experiments are carried out by using only LSCF as cathode. 


\subsection{Modification of the electrolyte microstructure of a Ni-CGO/CGO/LSCF-CGO cell and characterization under $\mathrm{R}=\mathrm{HC} / \mathrm{O}_{2}=\underline{0.21}$}

Even if porous electrolyte is not an issue in a single chamber SOFC configuration, Suzuki et al. [18] showed the influence of porosity on the OCV. Indeed, open porosity lets hydrogen and carbon monoxide diffuse freely from anode side to cathode side and consume oxygen by oxidation. Thus, oxygen partial pressure at the cathode side would be decreased and thereby OCV as well. Rembelski et al. [17] showed that a reduction of open porosity by increasing the electrolyte thickness led to higher OCV values and better electrochemical cell performances. Nevertheless a compromise has to be found because the ohmic loss is directly related to the electrolyte thickness [21].

As the electrolyte used in this work is not fully dense, cells with 3 different electrolyte thicknesses were prepared and characterized.

\subsubsection{Microstructure of the cells}

Electrolyte characteristics (thickness and porosity) of the 3 different cells, reported in table 3, are observed and measured by SEM micrographs analyses and ImageJ image processing program. Cells are named in reference with electrolyte thickness for the following results. The CGO-20 cell is the one used during the previous experiments (comparison of $\mathrm{R}$ ratios and cathode materials). Microstructures of electrolytes are reported in Figures 2 and 9. 
The increase of thickness leads to an increase of the electrolyte density. Indeed, porosity decreases from $12 \%$ for the cell with a $22 \mu \mathrm{m}$ thick electrolyte to $8 \%$ with a $43 \mu \mathrm{m}$ thick electrolyte. The performances of these different cells are evaluated under the $\mathrm{R}=0.21$ atmosphere.

\subsubsection{Comparison and performances}

Experiments are thus performed for cell with thicker electrolytes (CGO-30 and CGO-40) and polarization curves are reported in Figure 10. In order to compared these cells to the previous ones made with a CGO-20 electrolyte, OCV and maximum power density obtained under R=0.21 are reported in Figure 11 for the three cells.

As expected, a significant improvement of OCV values is noticed with the increase of electrolyte thickness by decreasing the open porosity from one electrode to the other and limiting gas diffusion through pores [17-18]. Open circuit voltage is thus enhanced thanks to an increased oxygen partial pressure gradient between electrodes. A higher maximum power density is thus induced especially at the highest temperatures. The best power density obtained is $25.1 \mathrm{~mW} \mathrm{~cm}$ at $550^{\circ} \mathrm{C}$ for the $\mathrm{CGO}-40$ cell. It shows that an electrolyte microstructure optimization carried out here, a pertinent selection of materials and architecture of the cell lead to better performances at lower temperature than work reported by Yano et al. and Nagao et al. [7-8]. However, further improvements could still be made by densification of the electrolyte. Indeed, the use of a thinner dense electrolyte would lower ohmic losses and also avoid gas cross diffusion problem.

\subsubsection{Electrochemical characterizations}


In order to complete these results and to evaluate the impact of the resistance of the cell on its performances, electrochemical impedance spectroscopy measurements are performed.

A Nyquist diagram corresponding to a typical Ni-CGO/CGO-20/LSCF-CGO cell tested under $\mathrm{R}=0.21$ at $600^{\circ} \mathrm{C}$ is reported in Figure 12.

Firstly, even if measurements are performed down to low frequencies $(25 \mathrm{mHz})$, the semicircle corresponding to electrode resistance contribution is not completed. That is probably due to gas diffusion limitations; as active species are largely diluted in nitrogen.

Secondly, considering the intercept of the diagram with real axis, which is usually considered as the ohmic resistance, it is important to mention that the measured value $0.3 \Omega \mathrm{cm}^{2}$ is much larger than expected from the cell. Indeed, with a $20 \mu \mathrm{m}$ thick CGO electrolyte, the ohmic resistance should be around $0.1 \Omega \mathrm{cm}^{2}$ if we consider a conductivity of $2.10^{-2} \mathrm{~S} \mathrm{~cm}^{-1}$ for dense and even porous CGO electrolyte at $600^{\circ} \mathrm{C}$ [22]. This phenomenon has already been reported in the literature [23] where the authors mentioned that this response in a relatively high frequency range (above $10 \mathrm{kHz}$ ) cannot be attributed only to electrolyte resistance but also to contact resistance. Indeed, in the present study, the cell is only placed between the gold meshes and there is no load applied to press the contact.

For all the studied cells, the shape of Nyquist diagrams is the same. The main conclusion is that the major resistance contribution comes from electrodes and not from electrolyte or contact resistance. Mass transfer and/or kinetics of electrode processes dominate the total resistance of the cell. That can be due to the low content of reactive species. Indeed, the atmosphere is highly diluted in $\mathrm{N}_{2}$ to fit exhaust gas stream composition.

In single chamber configuration, it is important to remind that the resistance of the cell is not only responsible of the overall performances. Indeed, the open circuit voltage, created thanks to an 
oxygen partial pressure gradient between the two electrodes, has a strong influence. Thus, even if the cells got nearly the same internal resistance, the higher the OCV is, the higher the performances will be, if no other phenomenon, such as electrode degradation, occurs.

\subsection{Focus on the energy recovery and emissions reduction results}

As the aimed application is to convert exhaust gases into electricity and reduce hydrocarbons emission, fuel utilization and $\mathrm{HC}$ conversion rate are calculated from results obtained from cell CGO-40 which has delivered the best performances at $550^{\circ} \mathrm{C}$ under $\mathrm{R}=0.21$.

\subsubsection{Fuel utilization}

In order to evaluate the ability of the cells to convert gas into electricity, fuel utilization is calculated according to equation 1 (with I: the delivered current at maximum power density) and is reported in Figure 13 for the CGO-40 cell versus temperature.

From $450^{\circ} \mathrm{C}$ to $600^{\circ} \mathrm{C}$, fuel utilization increases from about 2 to $4.5 \%$. Even if these values seem low, they are in accordance with literature for single chamber SOFC [24]. In the present work, it is noticeable that flow rate is quite high $\left(60 \mathrm{~L} \mathrm{~h}^{-1}\right)$ with a large $\mathrm{N}_{2}$ dilution. Therefore, the flow velocity around the cell is high $\left(\sim 0.6 \mathrm{~m} \mathrm{~s}^{-1}\right)$. Furthermore, gas distribution is not optimized and a large amount of reactive gas species flowed around the cell without being used for electrochemical reactions.

\subsubsection{Conversion rate of unburned hydrocarbons}


The conversion rate of hydrocarbons is another important factor for the application. Indeed, it allows to show the hydrocarbons emissions reduction released to the atmosphere. To show the capability of cells to decrease pollutant emission, $\mathrm{HC}$ conversion rate is calculated according to equation 3. The results obtained at the OCV with the Ni-CGO/CGO-40/LSCF-CGO cell are reported in Figure 14.

$\mathrm{HC}$ conversion rate increases from 9 to $17 \%$ as temperature increased from $450^{\circ} \mathrm{C}$ to $600^{\circ} \mathrm{C}$. This is in accordance with catalytic activity measurements of nickel. Indeed, the higher the temperature is, the more active towards HC conversion the nickel becomes [15]. The studied cell, that delivered the best performances at $550^{\circ} \mathrm{C}$, allowed to convert $15 \pm 3 \%$ of unburned hydrocarbons at this temperature.

\section{Conclusion}

This paper deals with an innovative concept of energy recovery from exhaust gas produced by a thermal engine. For this project, most performing cell architecture and cell materials were used in exhaust gas conditions at a realistic temperature range. Three different gas mixtures were investigated for an anode supported Ni-CGO/CGO/LSCF-CGO cell. The lowest oxygen containing ratio $(\mathrm{R}=0.67)$ was ruled out because of a huge carbon formation on the anode side. However, the other ratios $(\mathrm{R}=0.44$ and $\mathrm{R}=0.21)$ have delivered high power densities, reaching $15.2 \mathrm{~mW} . \mathrm{cm}^{-2}$ at $500^{\circ} \mathrm{C}$ for the oxygen richer ratio $(\mathrm{R}=0.21)$. PNO was also investigated as a new cathode material for single chamber SOFC. Although a greater open circuit voltage was created, the maximum power densities were lower than with LSCF material especially when the 
temperature was decreased from 600 to $450^{\circ} \mathrm{C}$. The formation of insulating phases on the PNO cathode during the cell operation has been enlightened and might be the cause of lower performances. Highest performances were obtained with a Ni-CGO/CGO-40/LSCF-CGO cell by increasing the electrolyte thickness up to $40 \mu \mathrm{m}$ in order to reduce the open porosity; a reduction of $15 \%$ of hydrocarbons emissions was possible and $25.1 \mathrm{~mW} \mathrm{~cm}^{-2}$ were delivered with a fuel utilization of $4.3 \%$ at $550^{\circ} \mathrm{C}$. Therefore, improved results compared to literature were reached at lower temperatures $\left(500-550^{\circ} \mathrm{C}\right)$, and with a gas mixture closer to real conditions.

\section{Acknowledgments}

The project was supported by ARC Energie, la Région Rhône-Alpes, France and by the CNRS via the Cellule Energie - INSIS.

\section{References}

[1] T. Hibino, K. Ushiki, T. Sato, Y. Kuwahara, Solid State Ion. 81 (1995) 1-3.

[2] I. Riess, P.J. van der Put, J. Schoonman, Solid State Ion. 82 (1995) 1-4.

[3] M. Kuhn, T. Napporn, Energies 3 (2010) 57-134.

[4] M. Yano, A. Tomita, M. Sano, T. Hibino, Solid State Ion. 177 (2007) 3351-3359.

[5] G. S. Herman, P. Mardilovich, D. Champion, C. Beatty (2004) Patent US20040166386.

[6] N. Uchiyama (2007) Patent WO2007094262 A1.

[7] M. Yano, T. Hibino, M. Nagao, K. Okamoto, A. Tomita, Y. Uchiyama, N. Uchiyama, Electrochem. Solid State Lett. 11 (2008) B29-B33. 
[8] M. Nagao, M. Yano, K. Okamoto, A. Tomita, Y. Uchiyama, N. Uchiyama, T. Hibino, Fuel Cells 8 (2008) 322-329.

[9] Z. Shao, C. Zhang, W. Wang, C. Su, W. Zhou, Z. Zhu, H. Park, C. Kwak, Angew. Chem.-Int. Ed. 50 (2011) 1792-1797.

[10] B.C.H. Steele, Solid State Ion. 129 (2000) 95-110.

[11] E.V. Tsipis, V.V. Kharton, J. Solid State Electrochem. 12 (2008) 1367-1391.

[12] P. Jasinski, T. Suzuki, X.D. Zhou, F. Dogan, H.U. Anderson, Ceram. Eng. Sci. Proc. 24 (2003) 293-298.

[13] C. Ferchaud, J.C. Grenier, Y. Zhang-Steenwinkel, M.M.A. van Tuel, F.P.F. van Berkel, J.M. Bassat, J. Power Sources, 196 (2011) 1872-1879.

[14] M. Rieu, P. K. Patro, T. Delahaye, E. Bouyer, Int. J. Appl. Ceram. Technol. 9 (2012) 10491057.

[15] P. Briault, M. Rieu, R. Laucournet, B. Morel, J.P. Viricelle, J. Mater. Sci. 48 (2013) 71847195.

[16] J. H. Koh, Y.S. Yoo, J.W. Park, H. Chun Lim, Solid State Ion. 149 (2002) 157-166.

[17] D. Rembelski, M. Rieu, L. Combemale, J.P. Viricelle, J. Power Sources 242 (2012) 811-816.

[18] T. Suzuki, P. Jasinski, V. Petrovsky, H. U. Anderson, F. Dogan, J. Electrochem. Soc. 152 (2005) A527-A531.

[19] Z. Shao, J. Mederos, W. Chueh, S. Haile, J. Power Sources 162 (2006) 589-596.

[20] A. Kovalevsky, V.V. Kharton, A.A. Yaremchenko, Y.V. Pivak, E.N. Naumovich, J.R. Frade, J. Eur. Ceram. Soc. 27 (2007) 4269-4272.

[21] LP. Sun, M. Rieu, J. P. Viricelle, C. Pijolat, H. Zhao, Int. J. Hydrogen Energ. 39 (2014) 1014-1022.

[22] C. Guizard, A. Julbe, O. Robbeb, S. Sarradeb, Catal. Today 104 (2005) 120-125. 
[23] P. Jasinski, T. Suzuki, F. Dogan, H.U. Anderson, Solid State Ion. 175 (2004) 35-38.

[24] N. Akhtar, S.P. Decent, D. Loghin, K. Kendall, J. Power Sources 193 (2009) 39-48. 


\section{Table captions}

Table 1. Experimental composition of gas species mixtures simulating an exhaust gas $(\mathrm{R}=$ $\left.\mathrm{HC} / \mathrm{O}_{2}\right)$

Table 2. Powders specifications (use for (A): Anode, (C): Cathode, (E): Electrolyte)

Table 3. Thickness and porosity of electrolytes of Ni-CGO/CGO-XX/LSCF-CGO cells (-XX refers to electrolyte thickness) 


\section{Figure captions}

Figure 1: Schema of experimental test bench (up) and schema and photographs of sample holder (down)

Figure 2. Micrograph of the Ni-CGO/CGO/LSCF-CGO cell cross section (electrolyte CGO-20) Figure 3. Micrograph of anode for $\mathrm{R}=0.67$ operated cell showing carbon particles formation Figure 4. Polarization curves of a Ni-CGO/CGO/LSCF-CGO cell operated in R=0.21 (on left) and $\mathrm{R}=0.44$ (on right) gas mixtures at different temperatures Figure 5. OCV (on left) and maximum power density (on right) versus temperature for NiCGO/CGO/LSCF-CGO cell under the ratios 0.21 and 0.44

Figure 6. Polarization curves of a Ni-CGO/CGO/PNO-CGO cell operated in $\mathrm{R}=0.21$ at different temperatures

Figure 7. OCV and maximum power density versus temperature for the investigated cathode materials under $\mathrm{R}=0.21$

Figure 8. X ray diffraction patterns of $\mathrm{PNO}$ cathode before and after test under $\mathrm{R}=0.21$ Figure 9. Micrographs of CGO-30 (left) and CGO-40 (right) cells Figure 10. Polarization curves of Ni-CGO/CGO/LSCF-CGO cells with different electrolyte thicknesses, CGO-30 on left and CGO-40 on right, operated in $\mathrm{R}=0.21$ at different temperatures Figure 11. OCV and maximum power density versus temperature for the 3 investigated electrolyte thicknesses

Figure 12. Nyquist diagram obtained on a Ni-CGO/CGO-20/LSCF-CGO cell operated in R=0.21 at $600^{\circ} \mathrm{C}$ 
Figure 13. Fuel utilization of the Ni-CGO/CGO-40/LSCF-CGO cell versus temperature for ratio $\mathrm{R}=0.21$

Figure 14. Hydrocarbons emissions reduction (HC conversion rate) of the Ni-CGO/CGO40/LSCF-CGO cell versus temperature for ratio $\mathrm{R}=0.21$ 
Tables

\begin{tabular}{cccccccc}
\hline $\mathbf{R}$ & $\mathbf{H C}(\boldsymbol{\%})$ & $\mathbf{C O}(\boldsymbol{\%})$ & $\mathbf{H}_{\mathbf{2}}(\boldsymbol{\%})$ & $\mathbf{O}_{\mathbf{2}}(\boldsymbol{\%})$ & $\mathbf{C O}_{\mathbf{2}}(\boldsymbol{\%})$ & $\mathbf{H}_{\mathbf{2}} \mathbf{O}(\boldsymbol{\%})$ & $\mathbf{N}_{\mathbf{2}}$ \\
\hline $\mathbf{0 . 2 1}$ & $0.098 \pm 0.003$ & $0.46 \pm 0.02$ & $0.47 \pm 0.01$ & $0.47 \pm 0.01$ & $5.03 \pm 0.02$ & $1.80 \pm 0.02$ & Balance \\
$\mathbf{0 . 4 4}$ & $0.098 \pm 0.003$ & $0.46 \pm 0.02$ & $0.47 \pm 0.01$ & $0.22 \pm 0.01$ & $5.03 \pm 0.02$ & $1.80 \pm 0.02$ & Balance \\
$\mathbf{0 . 6 7}$ & $0.098 \pm 0.003$ & $0.46 \pm 0.02$ & $0.47 \pm 0.01$ & $0.13 \pm 0.01$ & $5.03 \pm 0.02$ & $1.80 \pm 0.02$ & Balance \\
\hline
\end{tabular}

Table 1. Experimental composition of gas species mixtures simulating an exhaust gas $\left(\mathrm{R}=\mathrm{HC} / \mathrm{O}_{2}\right)$

\begin{tabular}{ccccc}
\hline Material & Formula & Supplier & $\begin{array}{c}\text { Particle mean } \\
\text { diameter, } \mathbf{d}_{\mathbf{5 0}} / \boldsymbol{\mu} \mathbf{m}\end{array}$ & $\begin{array}{c}\text { Specific surface } \\
\mathbf{a r e a}, \mathbf{S}_{\mathbf{B E T}} / \mathbf{m}^{\mathbf{2}} \mathbf{g}^{-\mathbf{1}}\end{array}$ \\
\hline LSCF (C) & $\mathrm{La}_{0.6} \mathrm{Sr}_{0.4} \mathrm{Co}_{0.2} \mathrm{Fe}_{0.8} \mathrm{O}_{3-\delta}$ & Fuel Cell Materials & 2 & 3.9 \\
$\mathbf{P N O}$ (C) & $\mathrm{Pr}_{2} \mathrm{NiO}_{4+\delta}$ & Marion Technologies & 0.5 & 4.2 \\
$\mathbf{N i O}(\mathbf{A})$ & $\mathrm{NiO}$ & Novamet & 1.5 & 3.5 \\
$\mathbf{C G O}(\mathbf{A})$ & $\mathrm{Ce}_{0.9} \mathrm{Gd}_{0.1} \mathrm{O}_{1.95}$ & Rhodia & 0.2 & 12 \\
$\mathbf{C G O}$ (E+C) & $\mathrm{Ce}_{0.9} \mathrm{Gd}_{0.1} \mathrm{O}_{1.95}$ & Fuel Cell Materials & 3.2 & 8.6 \\
\hline
\end{tabular}

Table 2. Powders specifications (use for (A): Anode, (C): Cathode, (E): Electrolyte)

\begin{tabular}{cccc}
\hline Number of screen-printed layers & Thickness $(\boldsymbol{\mu m})$ & Porosity $(\boldsymbol{\%})$ & Cell reference \\
\hline 3 & $22 \pm 1$ & $12 \pm 1$ & CGO-20 \\
5 & $31 \pm 1$ & $10 \pm 1$ & CGO-30 \\
7 & $43 \pm 1$ & $8 \pm 1$ & CGO-40 \\
\hline
\end{tabular}

Table 3. Thickness and porosity of electrolytes of Ni-CGO/CGO-XX/LSCF-CGO cells (-XX refers to electrolyte thickness) 


\section{Figures}

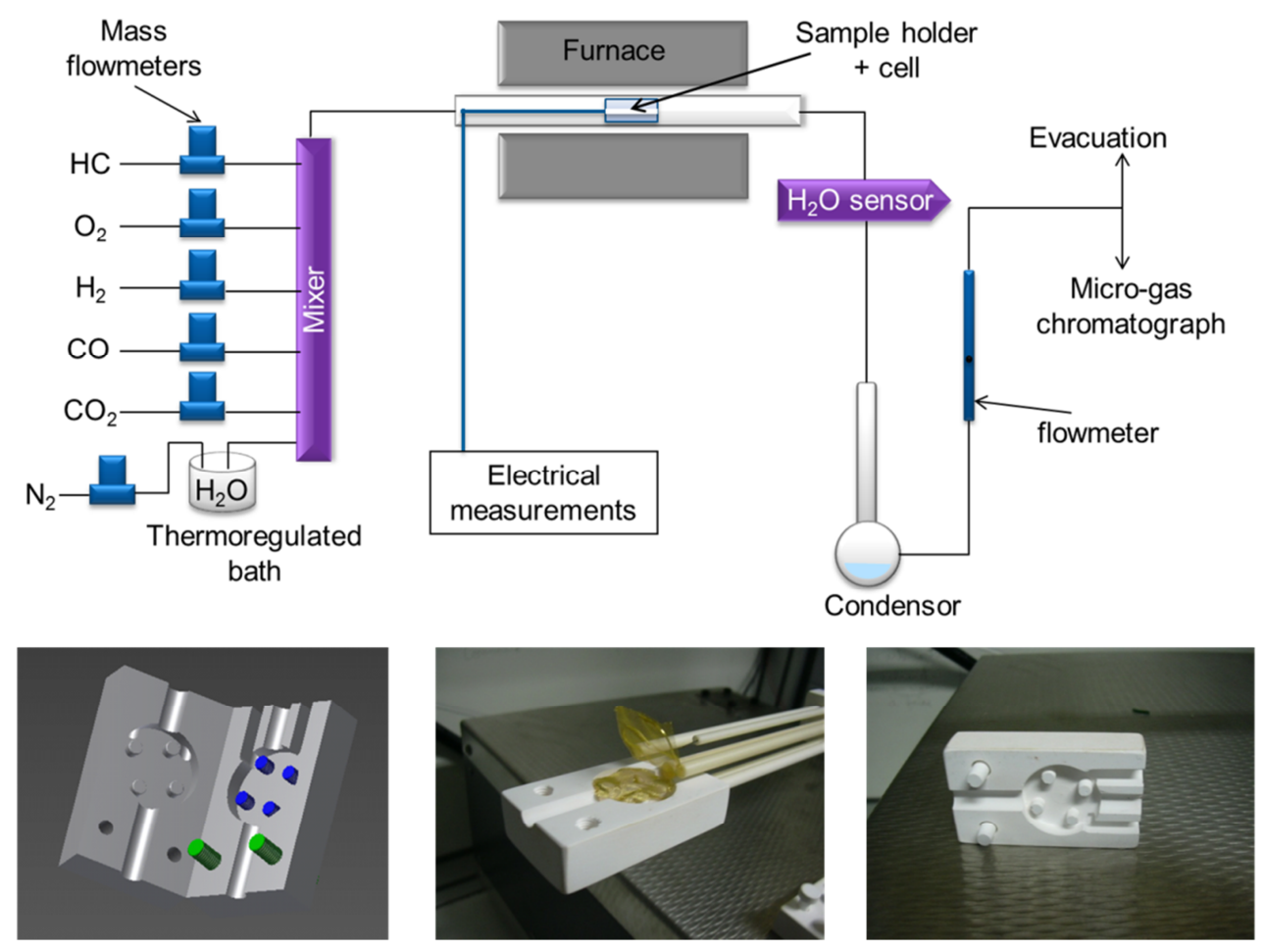

Figure 1: Schematic of experimental test bench (up) and schema and photographs of sample holder (down)

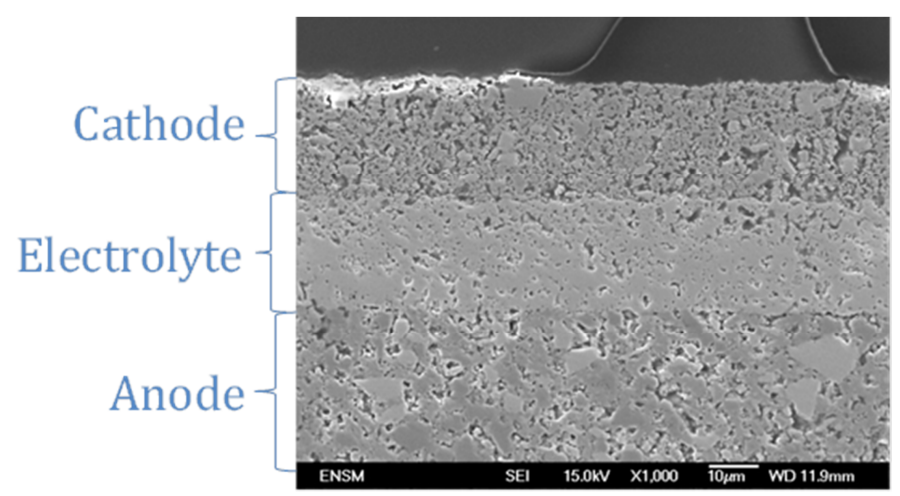

Figure 2. Micrograph of the Ni-CGO/CGO/LSCF-CGO cell cross section (electrolyte CGO-20) 


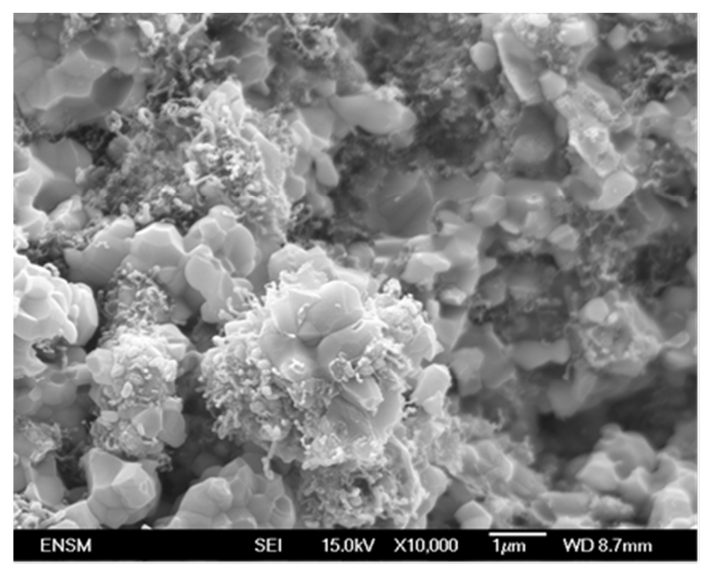

Figure 3. Micrograph of anode for $\mathrm{R}=0.67$ operated cell showing carbon particles formation
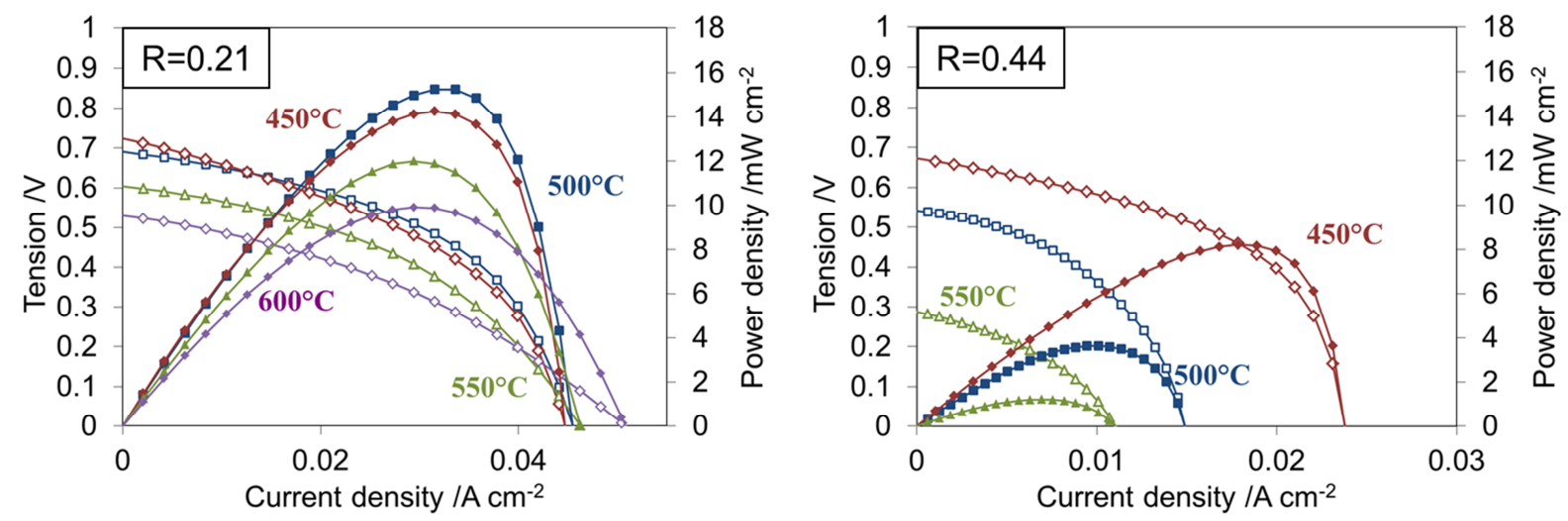

Figure 4. Polarization curves of a Ni-CGO/CGO/LSCF-CGO cell operated in R=0.21 (on left) and $\mathrm{R}=0.44$ (on right) gas mixtures at different temperatures
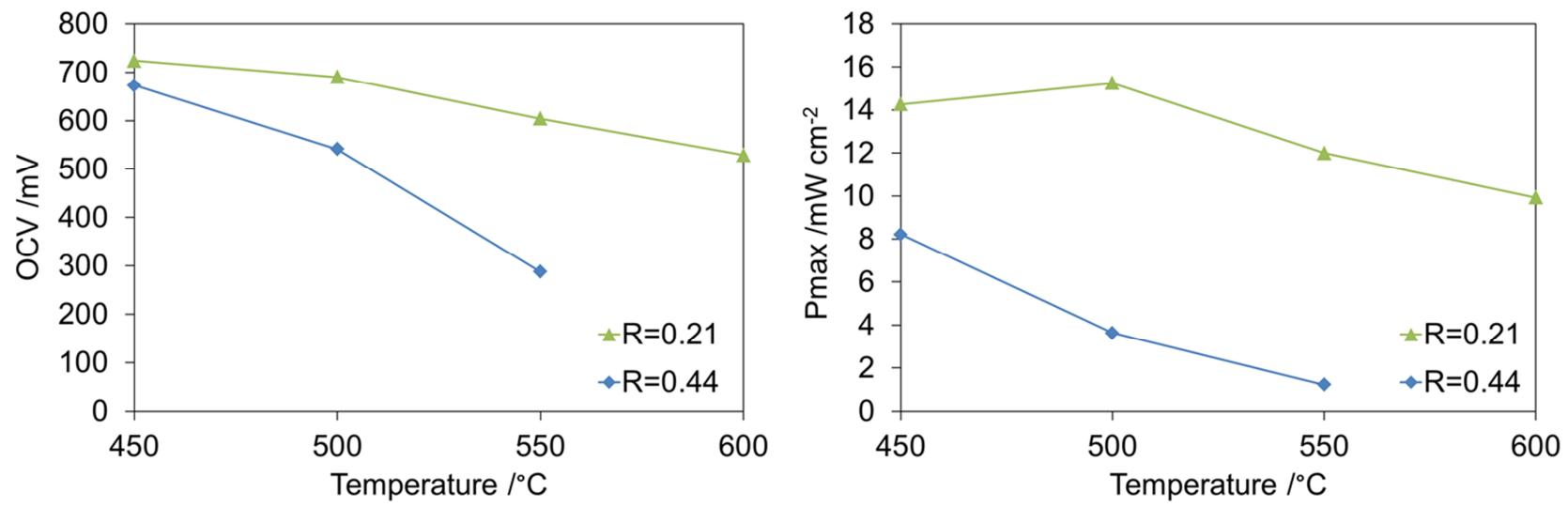

Figure 5. OCV (on left) and maximum power density (on right) versus temperature for Ni$\mathrm{CGO} / \mathrm{CGO} / \mathrm{LSCF}-\mathrm{CGO}$ cell under the ratios 0.21 and 0.44 


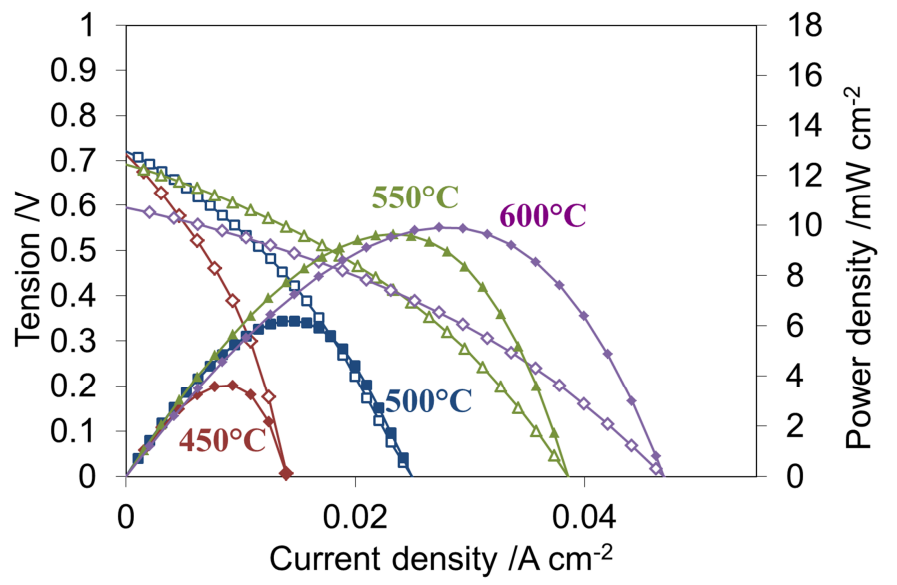

Figure 6. Polarization curves of a Ni-CGO/CGO/PNO-CGO cell operated in $\mathrm{R}=0.21$ at different temperatures
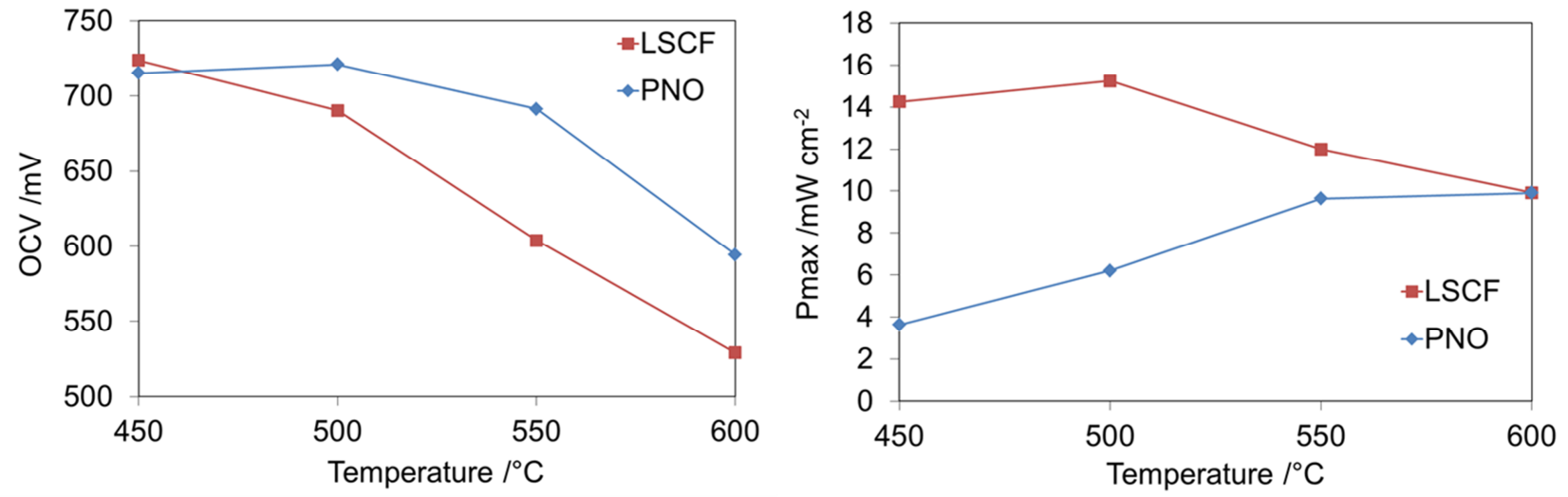

Figure 7. OCV and maximum power density versus temperature for the investigated cathode materials under $\mathrm{R}=0.21$ 


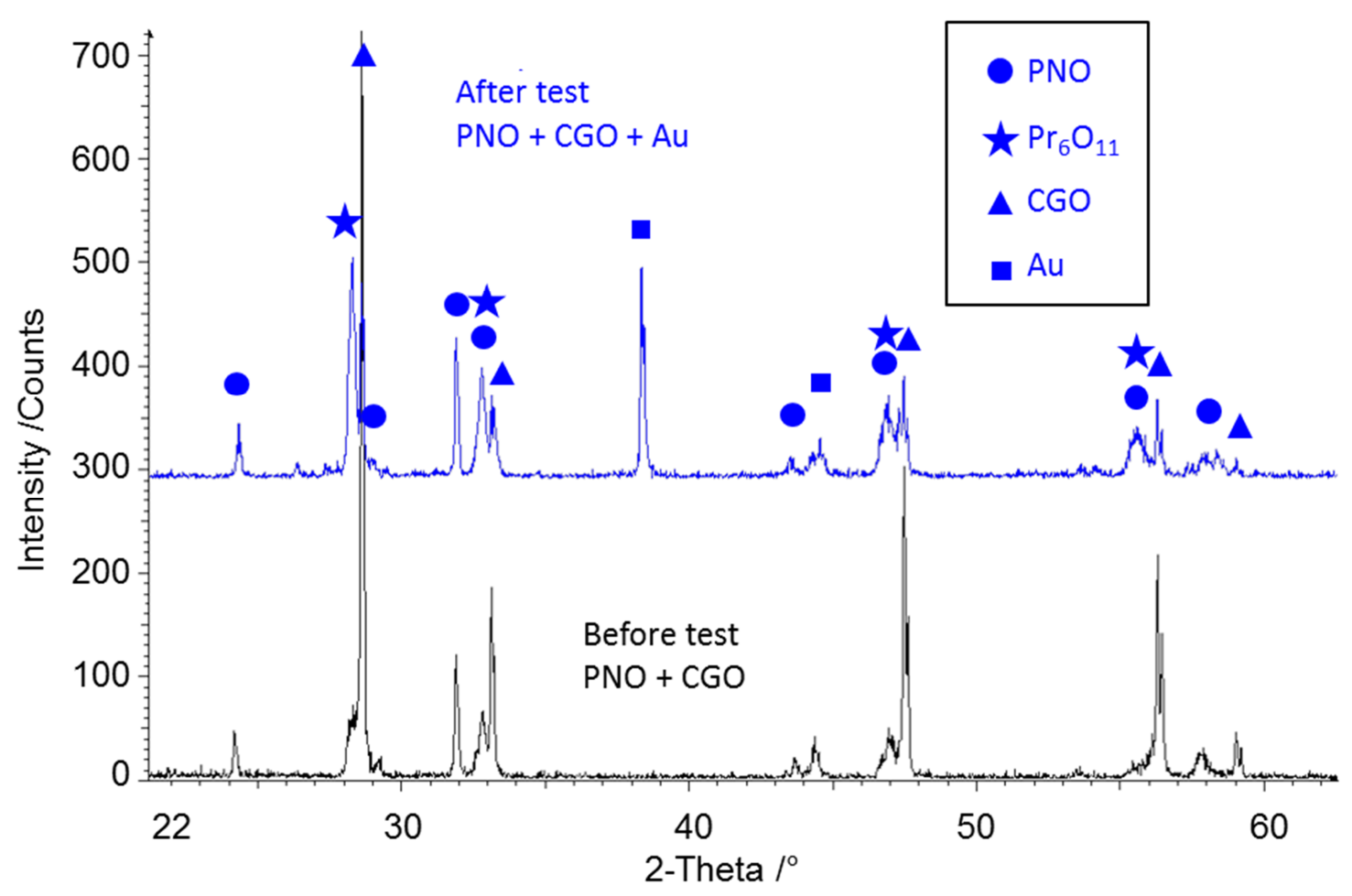

Figure 8. X ray diffraction patterns of PNO cathode before and after test under $\mathrm{R}=0.21$

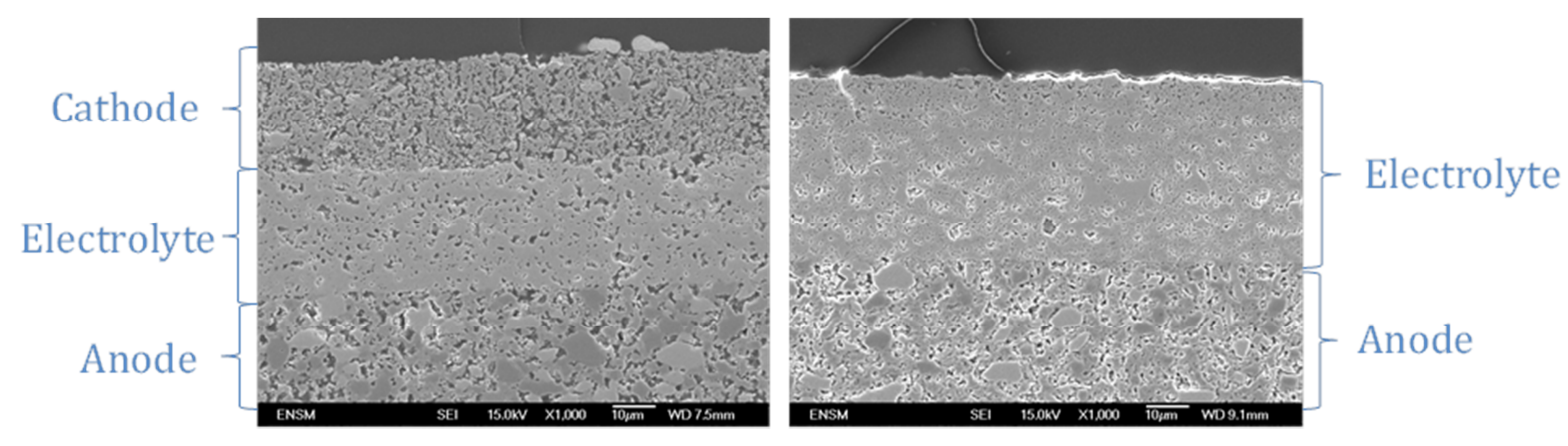

Figure 9. Micrographs of CGO-30 (left) and CGO-40 (right) cells 

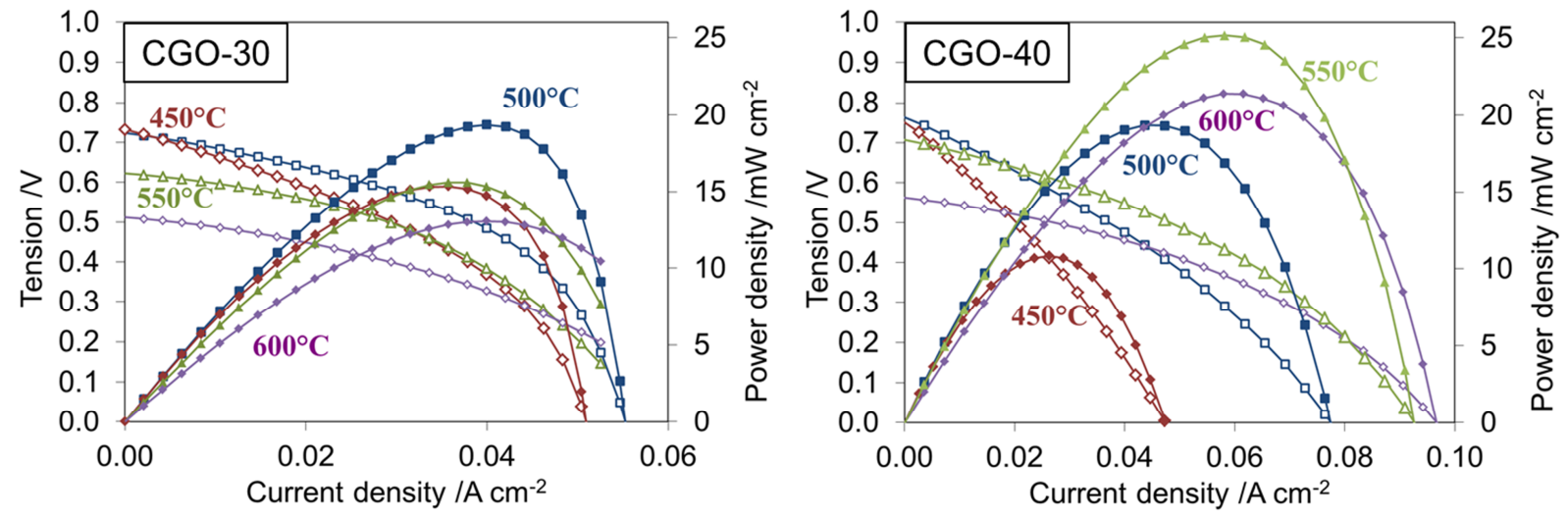

Figure 10. Polarization curves of Ni-CGO/CGO/LSCF-CGO cells with different electrolyte thicknesses, CGO-30 on left and $\mathrm{CGO}-40$ on right, operated in $\mathrm{R}=0.21$ at different temperatures
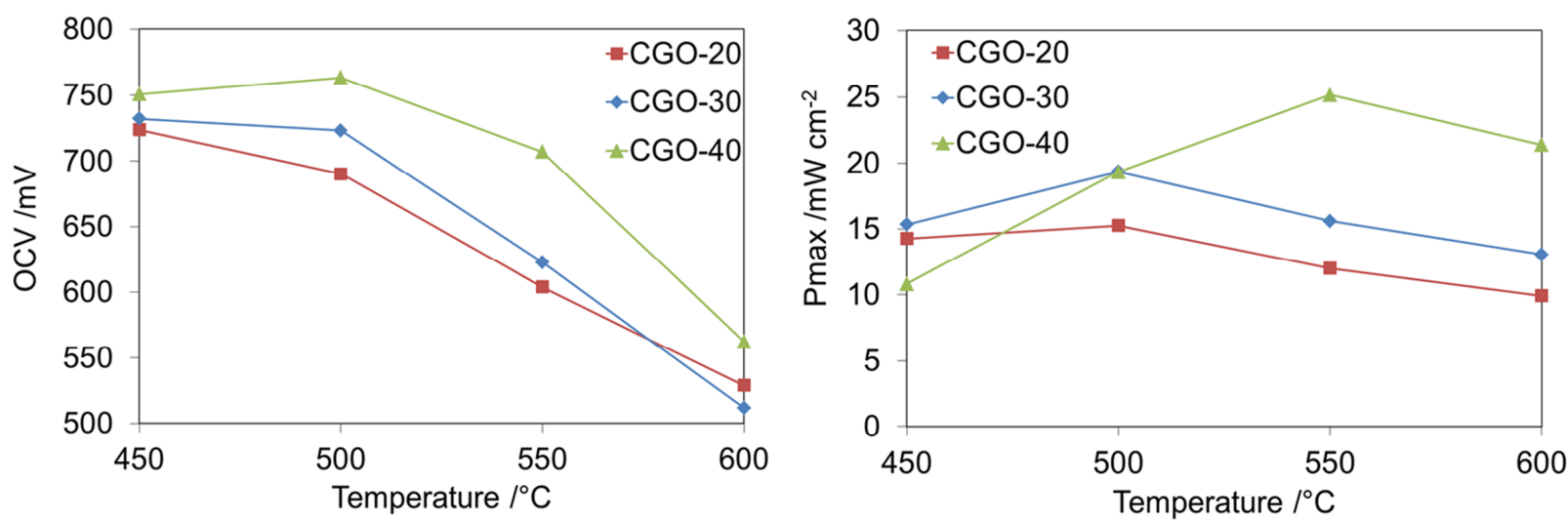

Figure 11. OCV and maximum power density versus temperature for the 3 investigated electrolyte thicknesses 


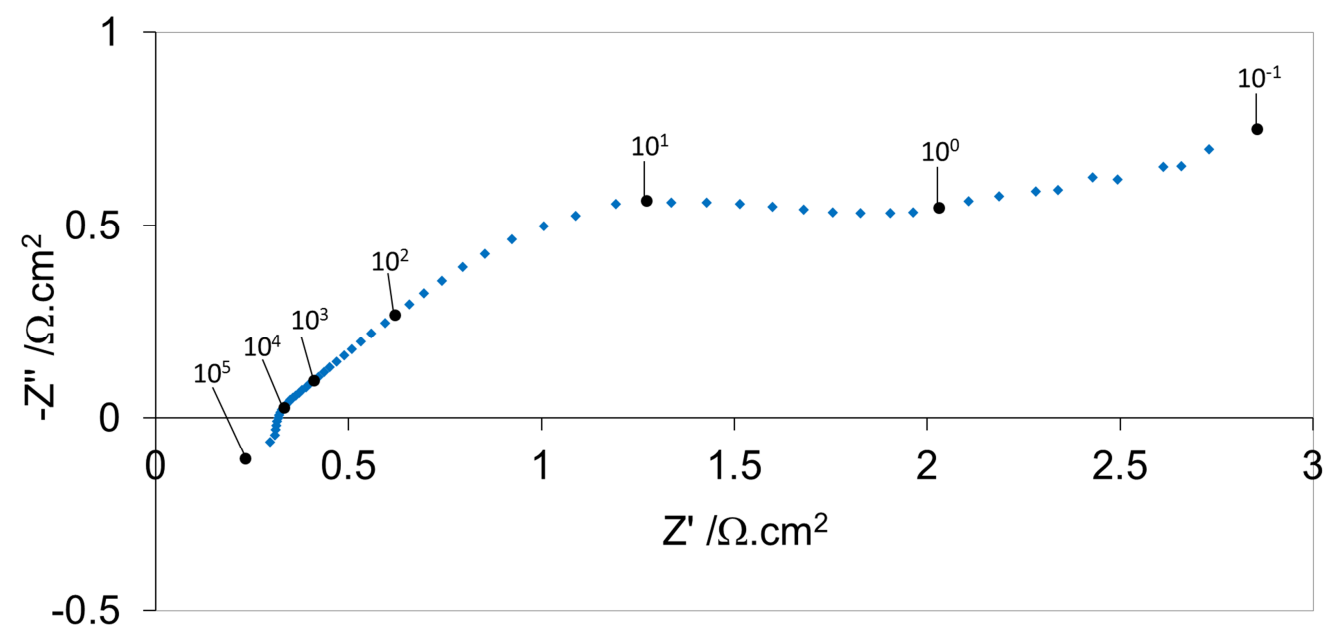

Figure 12. Nyquist diagram obtained on a Ni-CGO/CGO-20/LSCF-CGO cell operated in $\mathrm{R}=0.21$ at $600^{\circ} \mathrm{C}$

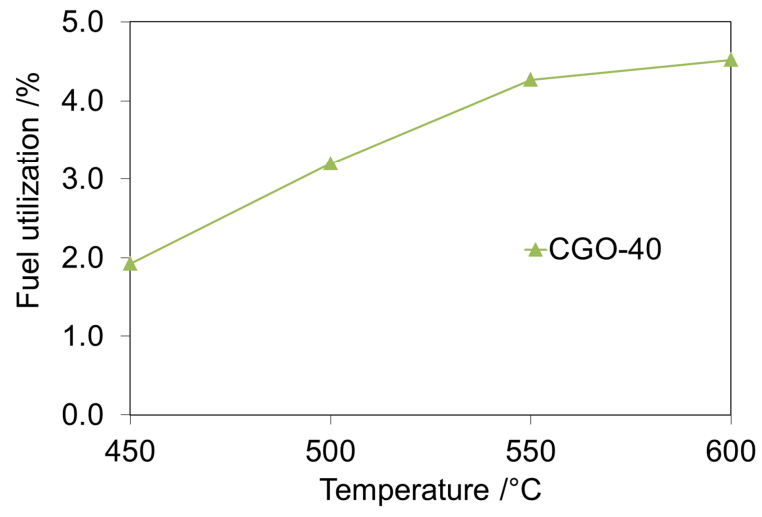

Figure 13. Fuel utilization of the Ni-CGO/CGO-40/LSCF-CGO cell versus temperature for ratio $\mathrm{R}=0.21$. 


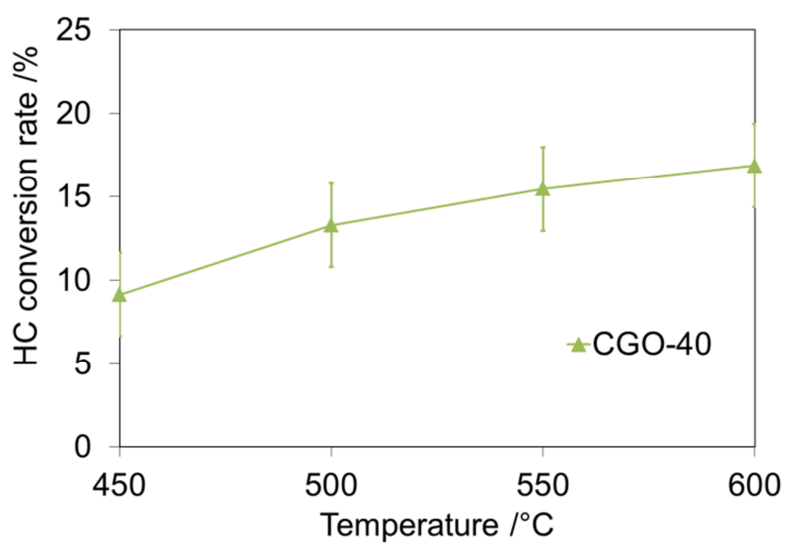

Figure 14. Hydrocarbons emissions reduction (HC conversion rate) of the Ni-CGO/CGO40/LSCF-CGO cell versus temperature for ratio $\mathrm{R}=0.21$. 